\title{
UK blood centres could play major role in gene therapy
}

London. Britain's public blood transfusion services could eventually evolve into a national "gene replacement" service under proposals tabled last week by a group of prominent medical scientists. The group suggests that, as gene therapy becomes more widely practised, the services' experience in collecting blood from donors and delivering it to hospitals could be adapted to the task of collecting cells and organizing their genetic manipulation before transplantation into patients.

The Scottish National Blood Transfusion Service (SNBTS) is already taking a small step in this direction. Researchers at its centre in Edinburgh will work with local university and hospital groups that are preparing gene-therapy experiments.

No such formal steps have yet been taken in England, where a national agency begins work on 1 April. However, its director, Harold Gunsen, said last week that involvement in gene therapy could become an important activity for blood transfusion services in the light of growing interest in synthetic blood substitutes produced by the biotechnology industry and declining demand for some conventional blood products. "Who knows, in 20 years this may be the main work of the transfusion centres", says Gunsen.

The idea of involving the transfusion services comes from a task force on gene therapy and transplantation set up by the Advisory Council on Science and Technology as part of a broader study of medical research and health (see Nature 361, 385; 1993). Chaired by Keith Peters, professor of medicine at the University of Cambridge, the task force was asked to look for ways of linking genetic research to social applications. It says that although a number of groups in Britain are likely to begin genetherapy experiments over the next few years, there will be several requirements that are "almost certainly" beyond the scope of most research laboratories in medical schools and research institutes.

In particular, monitoring for safety and "good manufacturing practice" will require expertise in handling cells and a sophisticated knowledge of retrovirology and other virus vectors, the task force says. "We believe that the infrastructures and some technical expertise is already available" within the transfusion services, it adds, suggesting that one or two centres should receive support for work in gene therapy and transplantation.

John Cash, medical and scientific director of the Scottish service, says that the task force's proposals "fit in well with what we are planning". He points out that the service already has expertise in molecular biology, and is involved in collecting stem cells, for example for use in leukaemia treatment. Preparing cells for gene therapy perhaps eventually including putting genes into cells - would therefore be a logical extension.

One advantage of involving the transfusion service in gene therapy is its good reputation. "People are used to the idea that the service handles products which are of human origin, and are then given to other patients," Peters says, adding that the service may help gene therapy to escape the consequences of a growing public distrust of scientific experts.

David Dickson

\section{US biotechnology groups select new executive}

Washington. Carl Feldbaum, 49, a lawyer with experience working for both Congress and the executive branch, has been chosen to head the new Biotechnology Industry Organization (BIO), the trade organization rep-

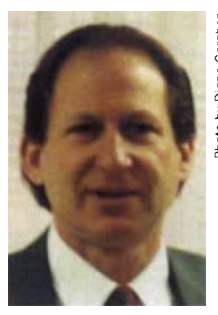

Carl Feldbaum resenting the US biotechnology industry after the merger next July of the two leading trade associations - the Association of Biotechnology Companies $(\mathrm{ABC})$ and the Industrial Biotechnology Association (IBA).

Steven Duzan, chairman and chief executive officer of Immunex Corporation and chairman of IBA, says that Feldbaum was given highest marks for his "tremendous capacity to absorb and to talk about technical information". For the past four years, Feldbaum was chief of staff for Senator Arlen Specter (Republican, Pennsylvania) and previously served both Democratic and Republican presidents as an assistant to the Secretary of Energy and as inspector general for defence intelligence in the US Department of Defense.

Richard Godown, president of IBA, and William Small, executive director of $\mathrm{ABC}$, will stay on as senior officials in the new trade organization.

Diane Gershon

\section{Chinese seize special issue of journal}

Washington. The Chinese government has muzzled a 72-year-old Chinese physicist and long-time human rights activist by confiscating all 20,000 copies of a scientific journal that devoted a recent issue to political reform in China. Western-style economic reforms cannot succeed without democratization and political freedom, wrote $\mathrm{Xu}$ Liangying in the October 1992 issue of Future and Development, an official publication of the China Association of Science and Technology.

"If Xu were 27 instead of 72 he would probably be in jail", says Richard Dicker of the New York-based Committee to End the Chinese Gulag, "but it would be a serious scandal for the government to arrest someone of his age". Xu sharply criticized the principles adopted by the recent 14th Party Congress in China in an article entitled "Without democracy there will be no reform", condemning government leaders for rejecting calls for reform while following "the nonsense and drivel uttered by liars, hoodlums and prostitutes". Jeffrey Mervis 